\title{
The Effect of Modified vs. Authentic Input on Iranian EFL Learners' Reading Comprehension
}

\author{
Farzad Taghavi \\ Department of English Language and Literature, Faculty of Humanities, Rasht Branch, Islamic Azad University, Rasht, \\ Iran \\ Farzaneh Aladini \\ Department of English Language and Literature, Faculty of Humanities, Rasht Branch, Islamic Azad University, Rasht, \\ Iran
}

\begin{abstract}
The present study investigated the effect of authentic input as a classroom activity on Iranian EFL learners' reading comprehension. This study intended to determine whether authentic reading materials could enhance Iranian EFL learners' reading comprehension at the upper-intermediate level. To achieve this goal, 46 language learners were randomly selected from 60 ones who attended Shokoh English Language Institute in Rasht, Iran. Quick Placement Test was conducted to homogenize the participants. They were divided into two groups: the experimental and control groups. The groups experienced identical conditions during the study except for their exposure to the independent variable. After administrating the pretest, the participants in the experimental group received the treatment. After eight sessions of the treatment, the posttest was administered to both groups of the study to find out the possible effect of authentic reading materials (independent variable) on the participants' reading comprehension skill (dependent variable). The results indicated that in the experimental group EFL learners' improvement in reading comprehension was significantly greater than those in the control group. This research is meant to improve EFL classes with respect to reading skill and to help English language publishers and teachers to see the unquestioning value of authentic texts.
\end{abstract}

Index Terms — authentic input, modified input, reading comprehension, EFL classroom

\section{INTRODUCTION}

Reading is considered one of the most important skills that EFL students need to acquire. According to Bowman, Levine, Waite, and Gendron (2010), reading is important not only in developing language intuition and determining academic success, but also for completing certain task. However, one measure which is used to make the process of teaching and learning more effective is related to selecting and adapting reading materials so that they can improve students' comprehension and vocabulary acquisition. Thus, the teacher should provide the students with the texts that can motivate and encourage them to keep reading eagerly.

Acquiring reading skill requires one to be able to comprehend the text itself. The researchers and experts have emphasized the important role that input comprehension plays in second language acquisition (SLA) theory. It is based on the fact that mere exposure to the target language does not provide language learners with the ideal condition. Investigations and studies have proved that input must be comprehended and digested by the learner if it is to assist the acquisition process. However, one of the critical problems that EFL students face is the lack of appropriate reading materials. Consequently, in many cases, reading has been ignored by most students due to the difficulty of understanding and comprehending the reading passages.

Without appropriate reading texts that suit them, students spend long hours in the classroom with poor achievement. Too often, foreign language reading texts are either too difficult or too easy for students. Students' performance varies according to the type of reading texts given to them. Moreover, many published reading textbooks in Iran, at present, often include the recorded materials of the written language in standard and formal English. As a result, the content of these materials is outdated with no contact with the actual world. Students feel bored if they always read the outdated materials, whose content is far away from their real life (Martinez, 2002). By introducing authentic materials to language learners, the instructors can help them to acquire a kind of independency when face the real life context (Larsen-Freeman, 2000).

Many language researchers and teachers consider authentic materials as powerful motivators because they are "more interesting or stimulating than artificial or non-authentic materials" (Peacock, 1997, p.144). One of the proponents of this view is Nuttall (1996) who states that "authentic texts can be motivating because they are proof that the language is used for real-life purposes by real people" (p. 172). Berardo (2006) found the advanced learners in his own classroom "highly motivated" because they found the authentic materials more "interesting", "stimulating" and "up to date" (p.66) than the traditional textbooks. 
Many authors (e.g. Field, 1998; Porter \& Roberts, 1981; Rings, 1986) claim that authentic materials are beneficial and advantageous to the foreign language classroom. The satisfactory outcome of any language program is "to prepare our students to cope with English outside the classroom" (Hafernik \& Surguine, 1979, p. 341). Thus it is strongly recommended that students experience the type of language that they are likely to encounter in the actual real world (Bacon, 1992; Ur, 1984). The other important advantage of authentic materials is that they "contain a wide variety of text types, language styles not easily found in conventional teaching materials" (Berardo, 2006, p. 65).

\section{REVIEW OF THE LITERATURE}

The term authentic material has been defined in different ways by researchers and experts. At first it may be helpful to look at a few definitions. Peacock (1997) defines authentic materials as the ones produced "to fulfil some social purpose in the language community ... that is, materials not produced for second language learners" (p. 146). Wallace (1992) believes that authentic materials are "real-life texts, not written for pedagogic purposes" (p.145). Morrow (1977) defines authentic text as "a stretch of real language, produced by a real speaker or writer for a real audience and designed to convey a real message of some sort" (p. 13). Harmer (1983) expresses his definition of this term in the following way: "Authentic texts (either written or spoken) are those which are designed for native speakers: they are real texts designed not for language students, but for the speakers of the language in question" (p. 146). Berardo (2006) differentiates between the authentic texts and non-authentic texts by pointing out that the language and structures of non-authentic materials are "artificial and unvaried", consequently, "make them very unlike anything that the learner will encounter in the real world and very often they do not reflect how the language is really used" (pp. 61-62).

The other key term, modified material, refers to textbooks or workbooks that are specially designed for pedagogical purposes. The language of modified materials has usually been modified and adjusted according to the learning objectives and level of learners and their abilities. According to Bacon and Finnemann (1990), the main difference between authentic and non-authentic or modified materials lies on the naturalness of language used. Authentic materials mirror the natural language used by the real people in the real life. No doubt every EFL learner wishes to be able to use her/his knowledge of language in the real situations in the actual world. Guariento \& Morely (2001) emphasize that nowadays language instructors are more conscious of the need to improve students' skills and make them ready for the real life communication, therefore, "teachers endeavour to simulate this world in the classroom" (p. 347).

Every EFL learner tries to master English language in order to be able to use it in actual real world. Now one wonders whether it is right to teach the artificial English language textbooks that are designed merely for language learning purposes and contain unnatural or artificial language. As Larsen-Freeman (2000) argues, when teachers are concerned with helping their students to develop reading skills, they should evaluate and improve not only their teaching methods but also teaching materials. Accordingly, the purpose of the present study is to focus on the effects of using authentic and modified text materials on learners' reading comprehension ability, which is very essential in the area of teaching English since it is one of the four basic language skills and it plays an important role in learning language and achieving higher levels of language proficiency.

A remarkable number of research projects and investigations have reported that comparing with modified texts, authentic texts are significantly more effective in improving students' four language skills: reading, writing, speaking and listening. Proponents of this view include (Guariento \& Morley, 2001; Paltridge, 2001; Peacock, 1997; Shrum \& Glisan, 2000). For example, several studies have shown that oral language development is improved when the practice incorporates authentic materials (Bacon \& Finneman, 1990; Miller, 2005; Otte, 2006; Thanajaro, 2000). Research also supports the notion that authentic materials can enhance reading comprehension by introducing students to new vocabulary and expressions (Bacon \& Finneman, 1990; Berardo, 2006; Otte, 2006) investigated whether aural authentic texts improved the listening comprehension skills of adult ESL students enrolled in an advanced listening course. His study proved that authentic materials developed the students' listening comprehension skills. Miller (2003), who conducted an investigation of authentic lectures, found that modified academic listening textbooks do not provide the students with the necessary skills to master the real lectures delivered at universities.

Besides the linguistic advantages, authentic materials have some non-linguistic advantages, too. All of us are aware of the significant role that motivation plays in a successful learning process, especially language learning. Many researchers (e.g., Allwright, 1979; Freeman \& Holden, 1986; Gilmore, 2007; Little \& Singleton, 1991; Sherman, 2003) believe that authentic materials have a strong positive effect on motivation. They believe that authentic materials can increase student motivation in the language classroom because they are more interesting and enjoyable. Kilickaya (2004) points out that authentic materials have positive effect on the learners' motivation, because they feel that they are practicing a real language used beyond the classroom. Both Thanajaro (2000) and Otte (2006) in their own studies proved that authentic materials increase learners' motivation. Berardo (2006) concludes that authentic materials are "highly motivating, giving a sense of achievement when understood and encourage further reading" (p. 67).

As it has been discussed authentic materials play significant role in increasing the learners' motivation for learning, and they provide a life-like setting where the learner can practice and improve her/his language skills. Nevertheless as Kilickaya (2004) points out there are still some teachers who are reluctant to use authentic materials in their own classrooms because they believe that these texts contain sophisticated language, complex structure and unusual vocabulary, consequently, they would not be suitable for the students at lower-level classes. For instance, Omaggio 
(1986) warns the teachers about the risks of using "unedited authentic materials" in their classrooms. He claims that since authentic texts are "random in respect to vocabulary, structure, functions, content, situation and length" they are actually impractical and highly problematic for the language instructors to "integrate successfully into the curriculum" (p.128). There were some researches with disappointing outcomes too. Kienbaum, Russell \& Welty (1986) who researched into the effect of authentic materials, found no statistically significant difference between the experimental and control groups. However, the results of an attitude survey revealed that all the students reacted favorably to the absence of traditional texts. Furthermore, some of the teachers complained that using authentic materials imposed new challenges on them. They claimed that finding suitable authentic texts, planning exercises and drills required considerable extra preparation time. Some other scholars like Guariento \& Morley (2001) again recommend the teachers at lower levels to select the texts that have "lexical and syntactic simplicity and content familiarity" otherwise the students may "feel frustrated, confused, and ... demotivated" (p. 348). Ur (1996) also warns the teachers against using authentic texts "with less proficient learners" because it might be "frustrating and counter- productive" (p.150). Indeed some of the EFL teachers may wonder, "are authentic materials too random and impractical for the classroom or can the right tasks alleviate those problems?" (Miller, 2005, p.12). No doubt, at intermediate and advanced levels a wide range of authentic materials are suitable for the classroom. However, when we are dealing with lower level classes, we should be more cautious. In fact the key of success lies in simplicity at both surface and deep layers of language: lexicon, syntax and culture.

The results of the above investigations, researches and studies have proved that the advantages of using authentic materials in EFL/ESL classrooms outweigh the disadvantages. Therefore, teachers would benefit from using authentic reading texts to improve their students' reading comprehension skills.

\section{Methodology}

This study was an experimental investigation on the effect of modified vs. authentic input on Iranian EFL learners' reading comprehension. It utilized a quantitative research method using a true-experimental design to test whether modified or authentic input has any effect on Iranian EFL learners' reading comprehension.

\section{A. Participants}

The present study investigated the effect of authentic input on Iranian EFL learners reading comprehension skill. To achieve this goal 46 EFL upper-intermediate level students (aged 16-25) were selected from the English learners enrolled in female adults' classes at Shokoh English Language Institute in Rasht, Iran.

\section{B. Materials and Procedures}

The present study comprised of five steps including administering QPT, random assignment, administering pre-test, applying experimental treatment to the participants, and administering post-test. In order to select a homogeneous sample the Quick Placement Test (QPT) was administered to 60 students. The test consisted of three parts with 60 items. Based on the standard of the test, the allotted time was 60 minutes. Having selected the participants based on the result of proficiency test, they were randomly assigned to the experimental and control groups. The researcher administered a pretest on the dependent variable (reading comprehension skill). Pretest and posttest designs compare students' performance before the treatment with their performance following the treatment.

Two types of material were used in this study: authentic materials and inauthentic materials. The reading materials and activities used in the control group were chosen from American English File (3) (Oxenden \& Latham-Koeing, 1997) that was used as the course book in the English language institute. The reading materials used for the experimental group were chosen from newspapers, internet magazine scripts and literature. Due to the difficulty of grading the authentic materials, the chosen authentic texts were validated by 4 teachers in the English language institute. All four teachers approximately confirmed that the authentic texts chosen for the experimental group matched with the students' level in terms of vocabulary, structure, culture and overall understanding of the texts. The pretest was administered to compare students' performance before the treatment with their performance following the treatment. An IELTS reading test was given to both experimental and control groups to assess the reading comprehension ability of them. After administration of the pretest, the treatment was carried out for 16 sessions for the experimental group and the placebo for the control group. Finally, to figure out the effect of the independent variables on the reading comprehension ability of the students, and to determine to what extent the treatment resulted in learning, an IELTS posttest was administered to the both groups. The researcher then compared the two groups' scores on the posttest.

The data were analyzed using SPSS statistical package, version 22. Based on the nature of the study, mean and standard deviation were computed for the pre and posttests scores collected from all participants. Then, a Paired Samples t-test and a one-way ANOVA were used in order to test whether there's a statistically significant difference between the means of the before-treatment test and the after-treatment test scores. Normality tests were used to check the normality of distribution. The procedures were conducted to figure out if authentic input would lead to better reading comprehension ability than modified input among Iranian EFL learners. Based on this premise, the null hypothesis "There is no statistically significant difference between the effect of using modified input or authentic input on the reading comprehension ability of Iranian EFL learners comparing" was presented. 


\section{RESULTS AND ANALYSIS}

To select homogenous sample, a total number of 46 EFL learners were selected out of 60 EFL learners who attended the QPT test and those who scored within the range of 31 to 40 in the test were selected as upper-intermediate group for the present study.

TABLE 4.1

\begin{tabular}{|c|c|c|}
\hline \multicolumn{3}{|c|}{ DESCRIPTIVE STATISTICS FOR THE QPT SCORES } \\
\hline $\mathrm{N}$ & Valid & 60 \\
\hline & Missing & 0 \\
\hline & & 27.77 \\
\hline & & 26.00 \\
\hline & & 24 \\
\hline & tion & 4.826 \\
\hline & & 31.742 \\
\hline & & 1.084 \\
\hline & of Skewness & .261 \\
\hline & & .225 \\
\hline & of Kurtosis & .463 \\
\hline & & 22 \\
\hline & & 17 \\
\hline & & 41 \\
\hline $\mathrm{Su}$ & & 2875 \\
\hline
\end{tabular}

Based on the findings of group statistics for the QPT scores (Table 4.1) that was given for picking out uniform sample with respect to general foreign language proficiency. Scores within the domain of 0-15 are considered Beginners, 16-23 (Elementary), 24-30 (Pre intermediate), and 31-40 (upper intermediate). The reliability of the reading comprehension pretest and posttest was estimated through Cronbach's Alpha. The findings of the reliability analysis are presented in Table 4.2.

TABLE 4.2

DESCRIPTIVE STATISTICS FOR THE PRETEST AND POSTTEST SCORES

\begin{tabular}{l|lll}
\hline & Cronbach's Alpha & N of Items & N of sample \\
\hline Reading comprehension ( pretest) & .825 & 32 & 46 \\
Reading comprehension ( posttest) & .796 & 32 & 46 \\
\hline
\end{tabular}

Based on the reliability criterion scale recommended by Barker, Pistrang, and Elliott (1994), the reliability of the pretest $\left(\alpha_{\text {pre-test }}=.825\right)$ and post-test $\left(\alpha_{\text {post-test }}=.796\right)$ of reading comprehension estimated was acceptably good and reliably appropriate for the analysis of the results.

\section{A. Descriptive Statistics for Pretest and Posttest}

According to Table 4.3, the mean score of the control group in the pretest is 12.60 and the minimum and maximum scores are 13 and 24, respectively. The mean score of the experiment group is 12.50 and the range of scores is from 13 to 25 .

TABLE 4.3

DESCRIPTIVE STATISTICS FOR THE PRETEST AND POSTTEST SCORES

\begin{tabular}{|c|c|c|c|c|c|c|}
\hline \multirow{11}{*}{ Statistic } & \multirow[b]{4}{*}{ Mean } & \multirow{10}{*}{$\begin{array}{l}\text { Lower Bound } \\
\text { Upper Bound }\end{array}$} & \multicolumn{2}{|c|}{ Pretest scores } & \multicolumn{2}{|c|}{ Posttest scores } \\
\hline & & & groups & & groups & \\
\hline & & & $\begin{array}{l}\text { control } \\
\text { group }\end{array}$ & $\begin{array}{l}\text { experimental } \\
\text { group }\end{array}$ & $\begin{array}{l}\text { control } \\
\text { group }\end{array}$ & $\begin{array}{l}\text { experimental } \\
\text { group }\end{array}$ \\
\hline & & & 12.60 & 12.50 & 13.25 & 20.56 \\
\hline & $95 \%$ Confidence & & 11.18 & 11.49 & 13.48 & 19.14 \\
\hline & Interval for Mean & & 15.03 & 14.52 & 15.11 & 22.95 \\
\hline & $5 \%$ Trimmed Mean & & 12.46 & 12.46 & 12.62 & 20.70 \\
\hline & Variance & & 32.29 & 24.31 & 29.46 & 40.01 \\
\hline & Std. Deviation & & 5.53 & 4.25 & 5.89 & 5.23 \\
\hline & Minimum & & 13.00 & 13.00 & 14.00 & 16.00 \\
\hline & Maximum & & 24.00 & 25.00 & 27.00 & 31.00 \\
\hline
\end{tabular}

The mean score of the control group in the post-test is 13.25 and the minimum and maximum scores are 14 and 27 , respectively. The mean score of the experiment group is 20.56 and the range of scores is from 16 to 31 .

As illustrated in Table 4.3, there was no statistically significant difference between the mean scores of the two groups on the reading comprehension pretest $(\mathrm{p}>.05)$. Thus, as Figure 4.1.displays, before receiving the treatment, both the experimental and control groups had the same proficiency level in terms of their reading comprehension ability.

B. Assessing the Normality of the Distributions 


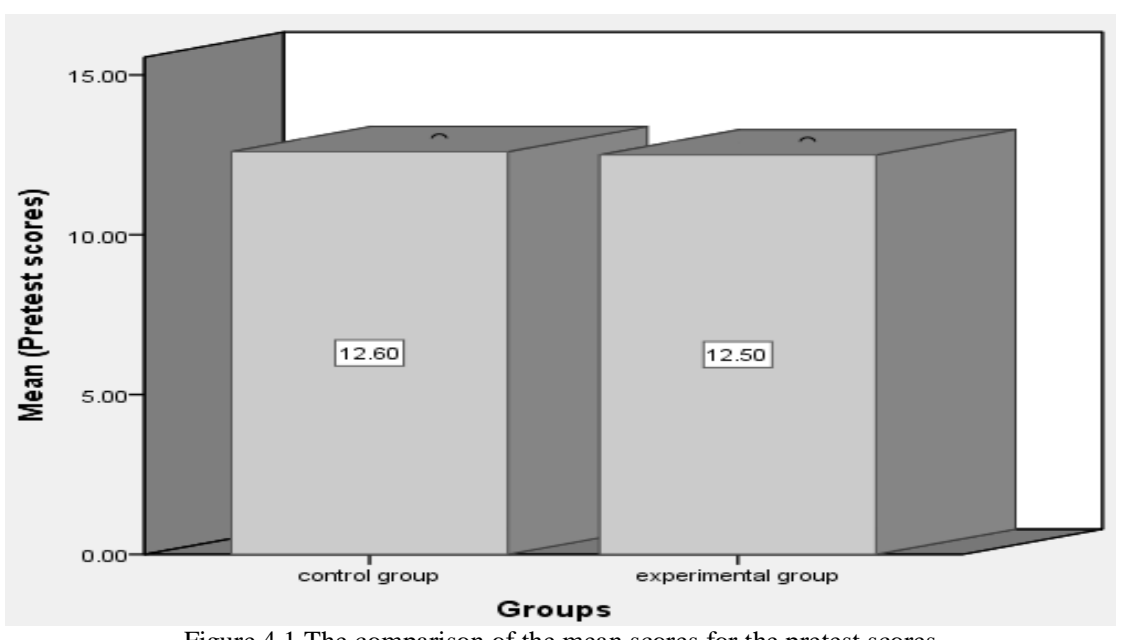

Figure 4.1 The comparison of the mean scores for the pretest scores

The assumption of normality was examined before running the main statistical analyses. To check the normality of the posttest scores the Kolmogorov-Smirnov test of normality was run. This was to confirm that parametric statistics could legitimately be applied to this case study. Table 4.4 displays the results of the test.

TABLE 4.4

\begin{tabular}{lc}
\multicolumn{2}{c}{ TABLE 4.4} \\
ONE-SAMPLE KOLMOGOROV-SMIRNOV TEST \\
\hline & Posttest scores \\
\hline Kolmogorov-Smirnov & .896 \\
Asymp. Sig.(2-tailed) & .399 \\
\hline
\end{tabular}

As Table 4.4 illustrates, Kolmogorov-Smirnov Z equals .896 and the p-value is .399 . We assume that the sampling distribution of the mean is normal thus parametric statistics could be used legitimately. A Pretest and posttest design is to compare the participants' performance before the treatment with their performance after receiving the treatment. In a pretest and posttest design, the researcher could measure the immediate effect of the given treatment. The main purpose was to determine to what extent the treatment resulted in improving the students' reading comprehension skill. At first the researchers were to find out whether the treatment was effective in developing the participants' reading comprehension skill from a statistical point of view. Thus, a paired-sample t-test was run. The results of the test are displayed in Tables 4.5 and 4.6.

TABLE 4.5

PAIRED SAMPLES STATISTICS

\begin{tabular}{|c|c|c|c|c|c|c|}
\hline groups & & & Mean & $\mathrm{N}$ & $\begin{array}{l}\text { Std. } \\
\text { Deviation }\end{array}$ & $\begin{array}{l}\text { Std. Error } \\
\text { Mean }\end{array}$ \\
\hline \multirow[t]{2}{*}{ Control group } & Pair 1 & Pretest scores & 12.60 & 23 & 6.51 & 1.188 \\
\hline & & Posttest scores & 12.80 & 23 & 6.20 & 1.131 \\
\hline \multirow[t]{2}{*}{ Experimental group } & Pair 1 & Pretest scores & 12.50 & 23 & 5.43 & .991 \\
\hline & & Posttest scores & 20.56 & 23 & 6.40 & 1.169 \\
\hline
\end{tabular}

The mean score of the control group for the reading comprehension test improved from $(\mathrm{M}=12.60)$ in pretest to (12.80) in posttest; that of the experimental group progressed from $(M=12.50)$ in pretest to (20.56) in posttest. As depicted in Tables 4.6, and 4.7 below, both control and experimental groups changed from pretest to posttest. Based on the results of paired t-tests, this improvement was statistically significant simply for the experimental group (P > .05), but not for the control group $(\mathrm{P}>$.05). In other words, the experimental group showed a significant improvement over the time as compared to the control group in the posttest.

TABLE 4.6

PAIRED SAMPLES T-TEST FOR READING COMPREHENSION PRETEST AND POSTTEST

\begin{tabular}{|c|c|c|c|c|c|c|c|c|c|c|}
\hline \multirow[t]{4}{*}{ Groups } & & & \multirow{2}{*}{\multicolumn{5}{|c|}{ Paired Differences }} & \multirow[t]{4}{*}{$\mathrm{t}$} & \multirow[t]{4}{*}{$\mathrm{df}$} & \multirow[t]{4}{*}{ Sig. ( 2-tailed) } \\
\hline & & & & & & & & & & \\
\hline & & & \multirow[t]{2}{*}{ Mean } & \multirow[t]{2}{*}{$\begin{array}{l}\text { Std. } \\
\text { Dev. }\end{array}$} & \multirow{2}{*}{$\begin{array}{l}\text { Std. } \\
\text { Error } \\
\text { Mean }\end{array}$} & \multicolumn{2}{|c|}{$\begin{array}{l}95 \% \text { Confidence Interval } \\
\text { of the Difference }\end{array}$} & & & \\
\hline & & & & & & Lower & Upper & & & \\
\hline control group & Pair 1 & $\begin{array}{l}\text { Pretest scores } \\
\text { Posttest scores }\end{array}$ & -.20 & 2.35 & .42 & -1.07 & .67 & -.46 & 29 & .64 \\
\hline $\begin{array}{l}\text { experimental } \\
\text { group }\end{array}$ & Pair 1 & $\begin{array}{l}\text { Pretest scores } \\
\text { Posttest scores }\end{array}$ & -8.06 & 3.99 & .72 & -9.55 & -6.57 & -11.07 & 29 & .00 \\
\hline
\end{tabular}

According to Table 4.6, since all p-values are less than .05 it is confirmed that the treatment has significantly improved the reading comprehension ability of the participants. A one-way ANOVA test was performed on posttest scores to determine if a statistically significant difference existed between the experimental group and the control group 
in the level of reading comprehension as measured using raw scores from the reading comprehension posttest. The result of this test is presented Table 4.7.

TABLE 4.7

TESTS OF BETWEEN-SUBJECTS EFFECTS

\begin{tabular}{llllll}
\hline & Type III Sum of Square & df & Mean Square & F & Sig. \\
\hline Group & 216.600 & 1 & 216.600 & 13.861 & .000
\end{tabular}

As Table 4.7 illustrates, the p-value is .000. In other words, the mean-score of the experimental group is significantly different from the mean-score of the control group. Since the mean-score of the experimental group on posttest is 20.56 and the mean-score of the control group on the posttest is 12.80 , it can be claimed that the experimental group has outperformed the control group. Since there was a statistically significant difference between the means $(\mathrm{p}<.05)$, the null hypothesis "There is no statistically significant difference between the effect of using modified input or authentic input on the reading comprehension ability of Iranian EFL learners comparing" was rejected.

\section{Results of Hypothesis Testing}

One of the advantages of a pretest and posttest design is that the researchers can recognize and determine the immediate effect of the treatment given to the experimental group. Before the treatment, the participants of the both groups sat for a pretest. To determine whether there was any statistically significant difference between the scores of the two groups in pretest, a paired sample t-test was run. The Sig. value was reported to be above the cut-off of 0.05 . This indicated that the two groups did not perform differently on the pretest. The experimental group received the treatment. After that the posttest was conducted .To determine whether there was any statistically significant difference between the scores of the control and experimental groups on the posttest, another paired sample t-test was run. This time our Sig value was less than 0.05 , indicating a statistically significant difference between the mean scores of the groups on the posttest. A one-way ANOVA test was performed on posttest scores to determine whether there was any statistically significant difference between the experimental and control groups. Results of the study indicated that, the null hypothesis of this study was rejected. It was concluded from the results that authentic materials could be more effective than modified materials in developing the reading comprehension skill of EFL learners at the upper-intermediate level. The following figure depicts the two groups' scores on the posttest at the end of the study.

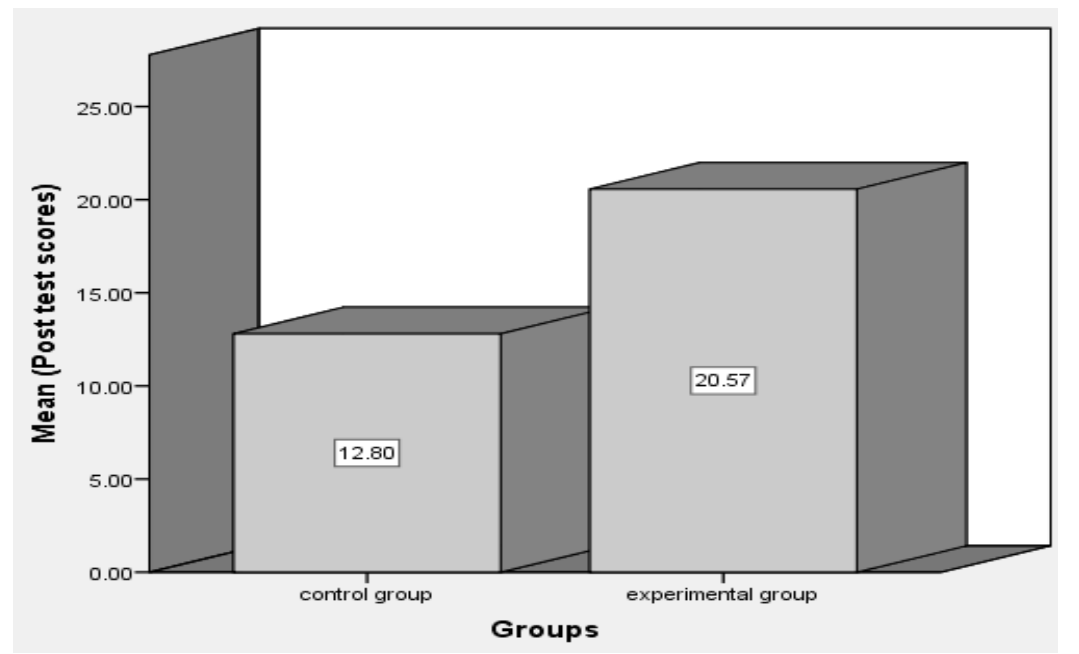

Figure 4.2. The comparison between the mean scores of control and experimental groups on posttest

As Figure 4.2 indicates, although the two groups were homogenous in terms of their reading comprehension as depicted by the results of the pretest at the beginning of the study, on the posttest the experimental group that received the experimental treatment significantly performed better than the control group that received the routine or traditional treatment.

According to the finding, the null hypothesis "There is no statistically significant difference between the effect of using modified input or authentic input on the reading comprehension ability of Iranian EFL learners comparing" was rejected. On the basis of the results the researchers claim that authentic materials were more effective than modified materials in improving the reading comprehension ability of Iranian EFL learners.

\section{DisCUSSION}

The present study investigated the impact of authentic and inauthentic materials on improving the reading comprehension ability of Iranian EFL learners. The researchers have found evidence for a strong relationship between authentic texts and the reading comprehension ability of upper-intermediate learners. Now they can claim that authentic reading materials can increase students' reading comprehension in an EFL situation at upper-intermediate level. In other 
words, the analysis of obtained data from pretests and posttests revealed that the use of authentic reading materials in EFL classroom enhanced students' reading comprehension ability. The students' reading comprehension appeared to improve significantly after exposure to authentic materials in the classroom.

The advantageous of using authentic materials in EFL/ESL classrooms have been increasingly acknowledged. Empirical studies (e.g., Bacon \& Finneman, 1990; Miller, 2005; Otte, 2006; Thanajaro, 2000; Yi, 1994) have proved that by providing opportunity for language learners to read authentic texts, good results can be achieved. These findings are supported by some other scholars (e.g., Bacon \& Finneman, 1990; Berardo, 2006; Dornyei \& Csizer, 2002; Guariento \& Morley, 2001; Peacock, 1997; Porter \& Roberts, 1981; Rogers \& Medley, 1988). In other words, by incorporating authentic materials into the language curriculum, students are empowered to join the real world and enjoy the experience of effective communication. Because as scholars such as (Harmer, 1983; Morrow, 1977; Wallace, 1992; Wilkins, 1976) emphasize, students experience using the "real language" produced by the "real speaker" who intends to convey a "real message" to the "real audience."

However, the finding is in contrast with some researches. Yi (1994) investigated the effects of using authentic versus edited texts on Korean and Japanese ESL learners at lower level of proficiency. According to their performance data, the two different types of texts had already the same impact on the learners' reading comprehension skills. In addition, Kienbaum, et al. (1986) who compared the impact of using traditional second language instruction and a communicative approach in second year French, German, and Spanish courses, found no significant difference between the experimental and control group. Nevertheless, an attitude survey showed that authentic materials increased the motivation of the experimental group. Moreover, the result of the study done by Aspari (2014) revealed that the use of authentic material in teaching reading did not significantly improve students' reading comprehension. In other words, the study indicated that the use of authentic reading text in comparison to created materials (non-authentic reading text) did not produce significantly better learning outcomes.

\section{CONCLUSION}

Due to its importance, a remarkable number of researches and studies have explored what constitute authentic input, why it is important, what makes it more effective in the language classrooms and how lesson planners and curriculum designers can support it. This study also examined the impact of using authentic input on the learner's reading comprehension skills in EFL classrooms. Our findings have proved that exposure to authentic materials has a positive impact on students' reading comprehension skills. The results from this study indicate that authentic input is more interesting and inspirational than artificial exercises and drills that EFL learners find in their own textbooks and supplementary materials, thus it must be included in the English language syllabus for EFL learners. Iranian students benefited from the exposure to the authentic materials which motivated further and deeper reading and empowered them to improve their comprehension skills. Using a variety of authentic resources helps the instructor to deepen and broaden the learners' understanding of the culture, customs, beliefs, values and rituals of the speakers of the target language. The learning environment should be similar to those that the learner would experience in the real world: watching TV, listening to the radio, attending a live theater, reading a poem, magazines and newspapers and etc. By reinforcing the link between class work and real-world, authentic input encourages students to practice adopting diverse roles and make them ready to join much readily the real life outside the classroom. Consequently, "once outside the 'safe', controlled language learning environment", (Berardo, 2006) the learner will be able to read and comprehend much more fluently the texts that are written for native speakers.

\section{REFERENCES}

[1] Allwright, R. (1979). Language learning through communication practice. In C. J. Brumfit \& K. Johnson (Eds.), The communicative approach to language teaching (pp.167-182). Oxford: Oxford University Press.

[2] Apsari, Y. (2014). The use of authentic materials in teaching reading comprehension. ELTIN Journal, 2, 88-94.

[3] Bacon, S. M. (1992). Phases of listening to authentic input in Spanish: A descriptive study. Foreign Language Annals, $25,317-$ 334. doi: 10.1111/j.1944-9720.1992.tb00552.x.

[4] Bacon, S. M., \& Finnemann, M. D. (1990). A study of the attitudes, motives, and strategies of university foreign language students and their disposition to authentic oral and written input. . Modern Language Journal, 74, 459-473.

[5] Berardo, S. A. (2006). The use of authentic materials in the teaching of reading. The Reading Matrix, 6(2), 60- 69.

[6] Bowman, L. L., Levine, L. E., Waite, B. M., \& Gendron, M. (2010). Can students really multitask? An experimental study of instant messaging while reading. Computers \& Education, 54(4), 927-931.doi: 10.1016/j.compedu.2009.09.024.

[7] Dörnyei, Z., \& Csizér, K. (2002). Some dynamics of language attitudes and motivation: Results of a longitudinal nationwide survey. Applied Linguistics, 23(4), 421-462. doi: 10.1093/applin/23.4.421.

[8] Field, J. (1998). Skills and strategies: Towards a new methodology for listening. ELT Journal, 52(2), 110-118. doi:10.1093/elt/52.2.110.

[9] Freeman, D. \& Holden, S. (1986). Authentic listening materials. In S. Holden (Ed.) Techniques of teaching (pp. 67-69). London: Modern English Publications.

[10] Gilmore, A. (2007). Authentic materials and authenticity in foreign language learning. Language Teaching, 40(2), 97-118. doi:10.1017/S0261444807004144

[11] Guariento, W., \& Morely, J. (2001). Text and task authenticity in the EFL classroom. ELT Journal, 55(4), 347-353. 
[12] Hafernik, J. J., \& Surguine, H. (1979). Using radio commercials as supplementary materials in ESL listening classes. TESOL Quarterly, 13, 341-345. http://dx.doi.org/10.2307/3585881.

[13] Harmer, J. (1991). The practice of English language teaching. London: Longman.

[14] Kienbaum, B. E., Russell, A. J. \& Welty, S. (1986). Communicative competence in foreign language learning with authentic materials. Final project report. Washington: Center for International Education, Purdue University.

[15] Kilickaya, F. (2004). Authentic materials and culture content in EFL classrooms. The Internet TESL Journal, 10(7).

[16] Larsen-Freeman, D. (2000). Techniques and principles in language teaching. Oxford: Oxford University Press.

[17] Little, D. \& Singleton, D. (1991). Authentic texts, pedagogical grammar and language awareness in foreign language learning. In C. James \& P. Garret (Eds.). Language awareness in the classroom (pp.123-132). London: Longman.

[18] Martinez, A. G. (2002). Authentic materials: an overview. In Karen's Linguistic Issues. Retrieved from http://www3.telus.net/linguisticsissues/authenticmaterials.html.

[19] Miller, M. (2005). Improving aural comprehension skills in EFL, using authentic materials: An experiment with university students in Nigata, Japan. MA dissertation, University of Surrey, Australia.

[20] Morrow, K. (1977). Authentic texts in ESP. In S. Holden (Ed.), English for specific purposes. London: Modern English Publications.

[21] Nuttall, C. (1996). Teaching reading skills in a foreign language. Oxford: Heineman.

[22] Omaggio, A. C. (1986). Teaching language in context. Boston: Heinle \& Heinle.

[23] Otte, J. L. (2006). Real language for real people: A descriptive and exploratory case study of the outcomes of aural authentic texts on the listening comprehension of adult English-as-a-second language students enrolled in an advanced ESL listening course. PhD dissertation, Loyola University Chicago, Chicago, IL, United States.

[24] Oxenden, C., Latham-Koenig, C. \& Seligson, P. (1997). American English File (3). New York: Oxford University Press.

[25] Paltridge, B. (2001). Genre and the language learning classroom. Michigan: University of Michigan.

[26] Peacock, M. (1997). The Effect of authentic materials on the motivation of EFL learners. English Language Teaching Journal, 51(2), 144-156.

[27] Porter, D., \& Roberts, J. (1981). Authentic listening activities. ELT Journal, 36(1), 37-47. doi: 10.1093/elt/36.1.37

[28] Rings, L. (1986). Authentic language and authentic conversational texts. Foreign Language Annals, 19, $203-208$. doi:10.1111/j.1944-9720.1986.tb02835.x.

[29] Rogers, C., V., \& Medley, F. W. Jr. (1988). Language with a purpose: Using authentic materials in the foreign language classroom. Foreign Language Annals, 21, 467-478. doi:10.1111/j.1944-9720.1988.tb01098.x.

[30] Sherman, J. (2003). Using authentic video in the language classroom. Cambridge: Cambridge University Press.

[31] Shrum, J. L., \& Glisan, E. W. (2000). Teacher's handbook: Contextualized language instruction. Boston: Heinle \& Heinle.

[32] Thanajaro, M. (2000). Using authentic materials to develop listening comprehension in the English as a second language classroom. PhD dissertation, Virginia Polytechnic Institute and State University, Blacksburg, Virginia.

[33] Ur, P. (1984). Teaching listening comprehension. Cambridge: Cambridge University Press.

[34] Ur, P. (1996). A course in English language teaching. Cambridge: Cambridge University press.

[35] Wallace, C. (1992). Reading. Oxford: Oxford University Press.

[36] Wilkins, D. A. (1976). Notional syllabuses. Oxford: Oxford University Press.

[37] Yi, J.M. (1994). The influence of authentic versus edited texts on the reading comprehension and online reading behaviors of beginning Korean and Japanese ESL students. PhD dissertation, University of Pittsburgh, Pennsylvania, USA.

Farzad Taghavi is an M.A. student in TEFL at Department of English Language and Literature, Faculty of Humanities, Rasht Branch, Islamic Azad University, Rasht, Iran. He is currently finishing his dissertation to obtain his M.A. degree.

Farzaneh Aladini is a lecturer at Department of English Language and Literature, Faculty of Humanities, Rasht Branch, Islamic Azad University, Rasht, Iran. Her research interests include English literature, composing haiku, teaching poetry and short story in EFL/ESL classes. 